\title{
Keterampilan Berpikir Tingkat Tinggi Siswa dalam Pembelajaran Inkuiri dengan Simulasi PheT: Studi Pendahuluan
}

\author{
${ }^{1}$ Ni Nyoman Sri Putu Verawati, ${ }^{2 \star}$ Roniati Sukaisih \\ ${ }^{1}$ Program Studi Pendidikan Fisika, FKIP Universitas Mataram, Jl. Majapahit No. 62 Mataram, \\ 83124, Indonesia \\ ${ }^{2}$ MAN 3 Lombok Tengah, Sengkol, Pujut, Lombok Tengah, 83573, Indonesia \\ *Email Korespondensi: roniatisukaisih@gmail.com
}

\begin{abstract}
Abstrak
Penelitian ini bertujuan untuk mengidentifikasi keterampilan berpikir tingkat tinggi siswa (HOTs) dengan indikatro analisis, evalusi, dan mencipta dalam pembelajaran inkuiri dengan simulasi PhET. Penelitian ini merupakan preeksperimental dengan one-group pretest-posttest design yang melibatkan 32 siswa sebagai subjek penelitian. Data keterampilan berpikir tingkat tinggi siswa dikumpulkan menggunakan instrument test berbentuk uraian. Keterampilan berpikir tingkat tinggi siswa dianalisis secara deskriptif menggunakan persamaan n-gain dan statistic menggunakan uji paired t-test dan Wilcoxon test dengan bantuan software IBM SPSS versi 23. Hasil penelitian menunjukkan pembelajaran inkuiri dengan simulasi PhET berpengaruh signifikan $(p<0,05)$ terhadap keterampilan berpikir tingkat tinggi siswa. Hasil analisis peningkatan ( $n$-gain) HOTs siswa juga menunjukkan peningkatan indicator analisis berkategori tinggi ( $n$-gain $=0,8$ ), sedangkan indicator evaluasi dan indicator mencipta berkategori sedang ( $\mathrm{n}$-gain= 0,7 dan $\mathrm{n}$-gain= 0,6). Berdasarkan temuan tersebut dapat disimpulkan bahwa pembelajaran inkuiri dengan simulasi PhET dapat meningkatkan keterampilan berpikir tingkat tinggi siswa pada materi bentuk dan perubahan energy.
\end{abstract}

Kata kunci: keterampilan berpikir tingkat tinggi (HOTs), inkuiri, simulasi PhET

\section{Students' Higher Order Thinking Skills in Inquiry Learning with PheT Simulation: Pre-Experimental Study}

\begin{abstract}
This study aims to identify students' higher order thinking skills (HOTs) with indicators of analysis, evaluation, and creation in inquiry learning with PhET simulation. This research is a pre-experimental with one-group pretestposttest design involving 32 students as research subjects. Data on students' higher order thinking skills were collected using a test instrument in the form of a description. Students' higher order thinking skills were analyzed descriptively using the $n$-gain equation and statistically using the paired $t$-test and Wilcoxon test with the help of IBM SPSS version 23 software. The results showed that inquiry learning with PhET simulation had a significant effect $(p<0.05)$ on students' higher order thinking skills. The results of the analysis of the increase (n-gain) of students' HOTs also showed an increase in the analytical indicators in the high category ( $n$-gain $=0.8)$, while the evaluation and creation indicators were in the medium category (n-gain $=0.7$ and $n$-gain $=0.6$ ). Based on these findings, it can be concluded that inquiry learning with PhET simulation can improve students' higher order thinking skills on the form and change of energy.
\end{abstract}

Keywords: higher order thinking skills (HOTs), inquiry, PhET simulation

How to Cite: Verawati, N. N. S. P., \& Sukaisih, R. (2021). Keterampilan Berpikir Tingkat Tinggi Siswa dalam Pembelajaran Inkuiri dengan Simulasi PheT: Studi Pendahuluan. Empiricism Journal, 2(1), 40-46. https://doi.org/10.36312/ej.v2i1.591

https://doi.org/10.36312/ej.v2i1.591

\section{PENDAHULUAN}

Keterampilan berpikir tingkat tinggi atau higher order thinking skills (HOTs) merupakan tujuan utama pendidikan (Mahanal, 2019) sekaligus tantangan dalam pelaksanaan pembelajaran sains (Kusuma et al., 2017). Berdasarakan tingkatan kognitif dalam taksonomi Bloom, analisis (C4), evaluasi (C5), dan mencipta/kreasi (C6) termasuk dalam indicatorindikator HOTs (Anderson \& Krathwohl, 2001). Brookhart (2010) mendefinisikan HOTs sebagai (1) transfer informasi dan pengetahuan melalui pembelajaran bermakna yang aktif, 
konstruktif, intensif, autentik, dan kooperatif (Mystakidis et al., 2019); berpikir kritis terkait berpikir reflektif untuk menentukan apa yang dipercaya dan dilakukan (Ennis, 2018); dan (3) pemecahan masalah melalui analisis untuk menemukan strategi-strategi pemecahan masalah yang paling efektif digunakan (Sukaisih et al., 2020). Beberapa keterampilan yang seringkali dikaitkan dengan HOTs diataranya berpikir kritis, berpikir kreatif, pemecahan masalah, berpikir logis (Singh et al., 2017; Zubaidah, 2019) metakognisi (Asy'ari, Hidayat, et al., 2019; Muhali, 2019; Thomas, 2012; Zohar \& Barzilai, 2013), dan keterampilan proses sains (Asy'ari, Fitriani, et al., 2019). Meskipun banyak hasil penelitian dan kajian teori yang menyatakan HOTs sebagai keterampilan penting dah harus dimiliki siswa sebagai bekal menghadapi tuntutan di masa depan (Diansah et al., 2021; Purnama \& Nurdianingsih, 2019), namun pada kenyataannya, pembelajaran yang menekankan keterampilan tingkat tinggi masih sering terabaikan (Annuuru et al., 2017). Pernyataan tersebut diperkuat hasil penelitian yang menunjukkan secara umum siswa tidak mengetahui konsep HOTs dan menunjukkan respon minimnya pembelajaran HOTs berdasarkan pengalaman belajar yang dilalui (Yuliati \& Lestari, 2018).

Hasil observasi menunjukkan bahwa rerata hasil ujian semester siswa adalah 55 sehingga menyebabkan $60 \%$ siswa harus melakukan remedial/ujian ulang. Kondisi tersebut salah satunya disebabkan oleh proses pembelajaran yang tidak mengharuskan siswa untuk melakukan langsung kegiatan-kegiatan pembuktian dalam pelajaran fisika yang dipelajari sehingga HOTs siswa tergolong rendah. Senada dengan uraian tersebut, Manalu (2019) menyatakan bahwa dalam pembelajaran fisika, guru belum menekankan untuk penguasaan HOTs pada siswa, hal tersbut terlihat dari penggunaan model pembelajaran yang bersifat semikonvensional. Lebih lanjut dijelaskan, siswa seringkali belajar dengan membaca, menghafal rumus, latihan soal, dan memahami konsep sehingga menyebabkan perbedaan hasil belajar fisika siswa termasuk HOTs (Fitriana et al., 2016) sehingga penggunaan pembelajaran yang memberikan perlakuan yang seragam penting dilakukan.

Salah satu pembelajaran yang seringkali digunakan untuk pembelajaran HOTs adalah pembelajaran inkuiri (Asy'ari et al., 2021; Prayogi \& Muhali, 2015). Pembelajaran inkuri merupakan pembelajaran berorientasi pada siswa (Arends, 2012) yang memiliki langkahlangkah mengidentifikasi masalah, membuat hipotesis, mengumpulkan data, menganalisis data, dan mengambil keputusan (Eggen \& Kauchak, 2012). Penelitian terkait penggunaan pembelajaran inkuiri untuk membelajarkan HOTs telah banyak dilakukan. Hasil penelitian Ita (2018) menemukan pembelajaran kooperatif berbasis dapat meningkatkan HOTs. Lebih lanjut, Purnamawati et al. (2017) yang menguji efektifitas lembar kerja siswa (LKS) berbasis inkuiri menyatakan bahwa LKS berbasis inkuri berpengaruh posistif dalam menumbuhkembangkan HOTs siswa dimana keterampilan analisis, evaluasi (n-gain: 0,6) dan mencipta (n-gain: 0,7) meningkat setelah pembelajaran. Kebaruan dari penelitian ini ditinjau dari uraian penelitian sebelumnya adalah perbedaan pada materi ajar yang digunakan yaitu materi bentuk dan perubahan energi dengan simulasi PhET yang merupakan jenis multimedia yang digunakan dalam pembelajaran keterampilan proses sains yang memiliki fitur animasi, video, gambar statis, dan simulasi yang interaktif. PhET awalnya dikembangkan dan digunakan dalam pembelajaran fisika, tetapi PhET kini sudah banyak digunakan dalam pembelajaran-pembelajaran matematika, kebumian, biologi dan kimia pada jenjang sekolah dasar, menengah dan universitas. Secara keseluruhan PhET dinyatakan dapat membantu siswa dalam memahami konsep dan juga meningkatkan keterampilan proses sains spesifik siswa dalam pemecahan masalah (PhET Interactive Simulations, n.d.). Penelitian ini bertujuan untuk mengidentifikasi keterampilan berpikir tingkat tinggi siswa (HOTs) dengan indikator analisis, evalusi, dan mencipta dalam pembelajaran inkuiri dengan simulasi PhET.

\section{METODE}

Penelitian ini merupakan penelitian pre-eksperimental dengan one group pretestposttest design (Fraenkel et al., 2012). Penelitian ini melibatkan 32 siswa di salahsatu Madrasah Aliyah Negeri di Lombok Tengah sebagai subjek penelitian. Data keterampilan berpikir tingkat tinggi siswa dikumpulkan menggunakan instrument test berbentuk uraian. Siswa terlebih dahulu diberikan tes awal $\left(\mathrm{O}_{1}\right)$ untuk mengetahui tingkat HOTs dan pengetahuan awal yang dimiliki pada materi bentuk dan perubahan energy. Siswa selanjutnya dibelajarkan menggunakan pembelajaran inkuiri dengan simulasi PhET (X). Pada tahap akhir, 
siswa diberikan tes akhir $\left(\mathrm{O}_{2}\right)$ untuk mengetahui perubahan/peningkatan HOTs siswa setelah dibelajarkan menggunakan pembelajaran inkuiri dengan simulasi PhET. Secara sederhana proses-proses tersebut disajikan pada Tabel 1.

Tabel 1. Desain penelitian one group pretest-posttest design

\begin{tabular}{ccc}
\hline Pretest & Perlakuan & Posttest \\
\hline $\mathrm{O}_{1}$ & $\mathrm{X}$ & $\mathrm{O}_{2}$ \\
\hline
\end{tabular}

Data HOTs siswa dianalisis menggunakan Kolmogorov-Smirnov test untuk menentukan normalitas data penelitian sebelum melakukan uji peningkatan keterampilan berpikir tingkat tinggi siswa menggunakan paired t-test jika dinyatakan berdistribusi normal dan Wilcoxon test jika data peneltian dinyatakan tidak berdistribusi normal. Analisis data secara statistic dilakukan dengan bantuan software IBM SPSS 23 version. Selain dianalisis secara statistic, peningkatan keterampilan berpikir tingkat tinggi siswa juga dianalisis secara deskriptif menggunakan persamaan n-gain (Persamaan 1) (Hake, 1999).

$n-$ gain $=\frac{\text { (skor posttest }- \text { skor pretest }}{\text { skor maksimum-skor pretest }}$

Skor n-gain yang diperoleh dari hasil analisis data penelitian selanjutnya dikategorisasikan menggunakan Tabel 2.

Table 2. Kriteria peningkatan HOTs siswa (n-gain)

$\begin{array}{cc}\text { Skor } & \text { Kategori } \\ \text { n-gain }>0,70 & \text { Tinggi } \\ 0,30-0,70 & \text { Sedang } \\ \text { n-gain }<0,30 & \text { Rendah }\end{array}$

Selain kategorisasi peningkatan siswa setelah pembelajaran menggunakan pembelajaran inkuiri dengan simulasi PhET, HOTs siswa juga dikategorisasi berdasarkan Tabel 3.

Tabel 3. Kategori HOTs siswa (Kusuma et al., 2017)

\begin{tabular}{cc}
\hline Skor & Kategori \\
\hline $76-100$ & Unggul \\
$56-75$ & Baik \\
$26-55$ & Cukup \\
$1-25$ & Rendah \\
\hline
\end{tabular}

\section{HASIL DAN PEMBAHASAN}

Hasil

Uji prasyarat menggunakan Kolmogorov-Smirnov test dilakukan sebelum uji peningkatan keterampilan berpikir tingkat tinggi siswa (Tabel 4). Berdasarkan hasil analisis data. Indikator analisis dan mencipta dinyatakan berdistribusi normal, sedangkan indicator evaluasi dinyatakan tidak berdistribusi normal, sehingga uji paired t-test dilakukan untuk data berdistribusi normal, dan Wilcoxon test untuk data tidak berdistribusi normal.

Table 4. Normalitas data penelitian

\begin{tabular}{lcccc}
\hline \multirow{2}{*}{ Item } & \multirow{2}{*}{$\mathbf{N}$} & \multicolumn{3}{c}{ Keterampilan berpikir tingkat tinggi } \\
\cline { 3 - 5 } & & Std. Deviation & Sig. & Normalitas \\
\hline Analisis & 11.74 & 0,200 & Ya \\
Evaluasi & \multirow{2}{*}{32} & 11.31 & 0,0003 & Tidak \\
Mencipta & & 9.88 & 0,200 & Ya \\
\hline
\end{tabular}

Tabel 4 menunjukkan bahwa indicator evaluasi dinyatakan tidak berdistribusi normal (sig. < 0,05) sehingga Wilcoxon test dilakukan untuk menentukan peningkatan indicator tersebut setelah pembelajaran menggunakan pembelajaran inkuiri dengan simulasi PhET. Berbeda dengan indicator evaluasi, indikator analisis dan indicator mencipta dinyatakan berdistribusi normal (sig. > 0,05) sehingga paired t-test dilakukan untuk menentukan peningkatan indicator analisis dan mencipta siswa setelah pembelajaran.

Table 5 menunjukkan peningkatan (n-gain) HOTs siswa berdasarkan tiap indicator. Hasil penelitian menunjukkan bahwa pembelajaran inkuiri dengan simulasi PhET 
berpengaruh signifikan terhadap HOTs siswa pada tiap indicator yaitu analisis, evaluasi, dan mencipta.

Table 5. Hasil analisis paired t-test, Wilcoxon test, dan n-gain HOTs siswa

\begin{tabular}{|c|c|c|c|c|c|c|c|c|}
\hline & Item & Tes & $\mathbf{N}$ & Mean & Std. Deviation & Df & $\mathbf{p}$ & n-gain \\
\hline Pair 1 & Analisis & $\begin{array}{l}\text { Pretest } \\
\text { Posttest }\end{array}$ & 32 & $\begin{array}{l}31.12 \\
90.18\end{array}$ & $\begin{array}{c}11.90 \\
9.27\end{array}$ & 31 & 0,000 & 0,8 \\
\hline Pair 2 & Mencipta & $\begin{array}{l}\text { Pretest } \\
\text { Posttest }\end{array}$ & 32 & $\begin{array}{l}23.21 \\
77.41\end{array}$ & $\begin{array}{l}10.79 \\
14.11\end{array}$ & 31 & 0,000 & 0,6 \\
\hline \multicolumn{9}{|c|}{ Wilcoxon test } \\
\hline \multicolumn{2}{|c|}{ Item } & $\mathbf{z}$ & & & $\mathbf{p}$ & & & n-gain \\
\hline \multicolumn{2}{|c|}{ Evaluasi } & -4.944 & & & 0,000 & & & 0,7 \\
\hline
\end{tabular}

\section{Pembahasan}

Pembelajaran inkuiri dengan simulasi PhET memberikan dampak signifikan terhadap HOTs siswa $(p<0,05)$. Temuan tersebut juga didukung dengan peningkatan HOTs siswa berdasarkan tinjauan indicator-indikator HOTs yang diukur dalam penelitian ini (Gambar 1). Pembelajaran inkuiri yang menekankan pada keterlibatan aktif siswa dalam menemukan pengetahuan melalui proses analisis dan kegiatan percobaan menyebabkan terjadinya peningkatan HOTs siswa. Sejalan dengan pernyataan tersebut, Rohmawatiningsih et al. (2018) menyatakan bahwa keterlibatan langsung dalam pembelajaran dan situasi nyata merupakan kegiatan penting dalam membelajarkan keterampilan berpikir tingkat tinggi. Lebih lanjut Hunaepi et al. (2020) menjelaskan pembelajaran inkuri membantu siswa dalam membangun pengetahuan melalui kegiatan bertanya, merumuskan hipotesis, dan menguji hipotesis untuk membangun pemahaman mendalan terhadap pengetahuan tersebut.

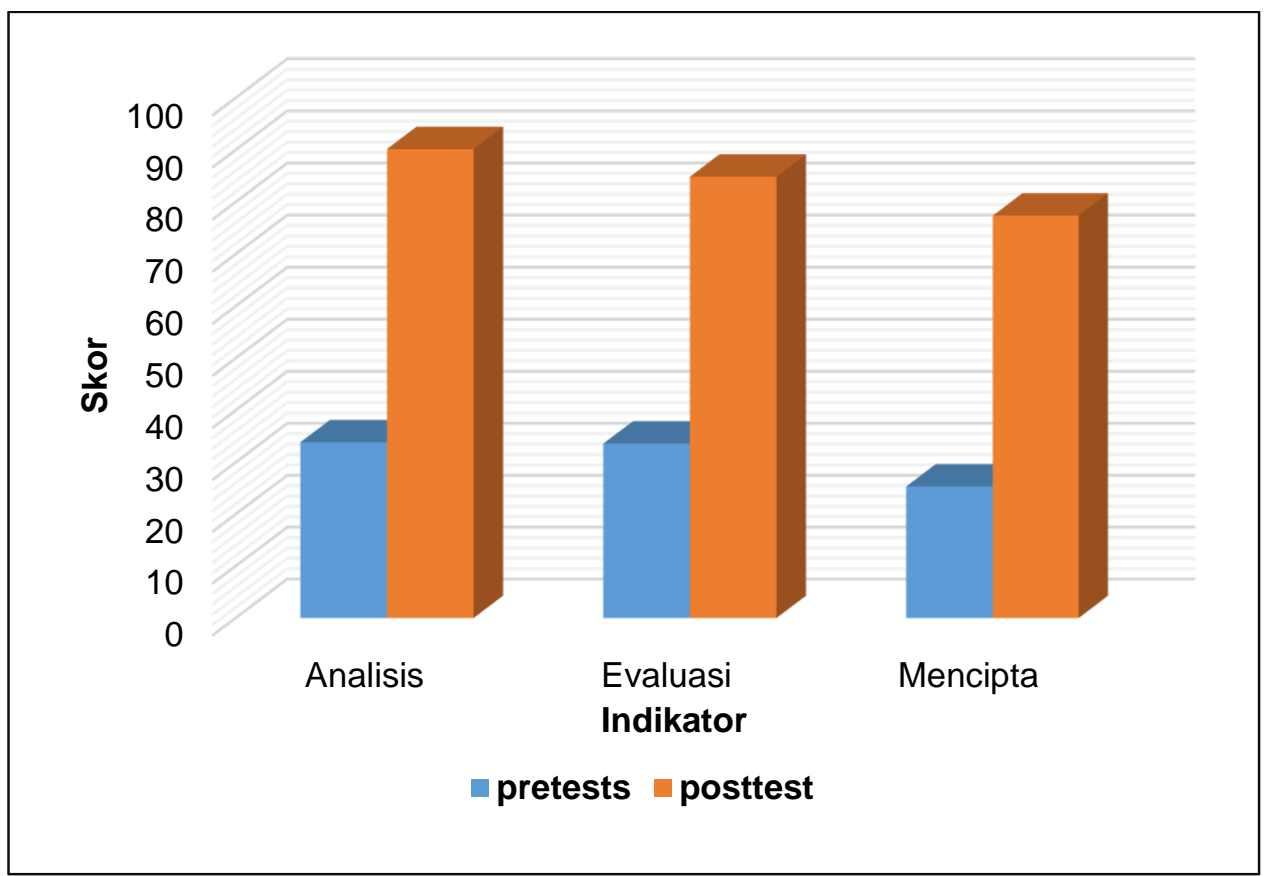

Gambar 1. Peningkatan HOTs siswa berdasarkan tinjauan indicator

Peningkatan HOTs siswa setelah pembelajaran inkuri dengan kategori tiap indicator yaitu analisis berkategori tinggi (n-gain: 0,8); evaluasi berkategori sedang (n-gain: 0,7$)$; dan mencipta berkategori sedang (n-gain: 0,6$)$ tidak terlepas dari penggunaan simulasi PhET sebagai media aktualisasi konsep-konsep fisika yang bersifat abstark pada materi bentuk dan perubahan energy (Gambar 2). 


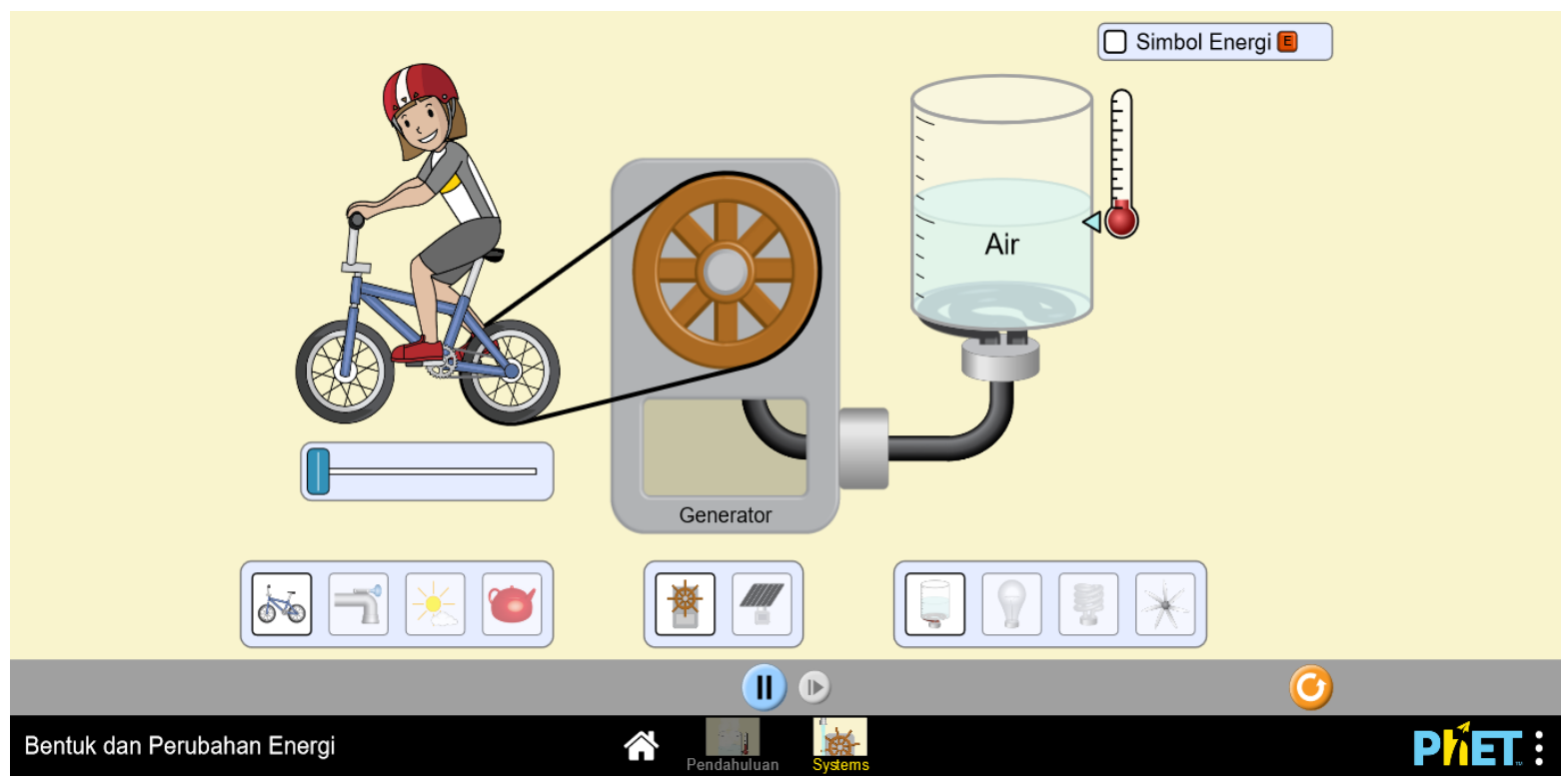

Gambar 2. Materi ajar bentuk dan perubahan energy pada simulasi PhET

Simulasi materi ajar pada media simulasi PhET memiliki karakteristik interaktif dengan menampilkan gambar statis, animasi, video, dan simulasi membuat siswa lebih tertarik selama proses pembelajaran. Sejalan dengan pernyataan tersebut, penelitian terdahulu menyatakan PhET menyediakan gambar, animasi, dan simulasi interaktif yang dibuat seperti permainan (Thohari et al., 2019) sehingga berdampak pada aktifitas dan antusiasme siswa dalam pembelajaran (Pujiyono et al., 2016) peningkatan pemahaman konsep fisika siswa (Batuyong \& Antonio, 2018). Selain itu, tampilan pada simulasi PhET yang menarik juga disinyalir mempengaruhi rasa ingin tahu siswa (Mahulae et al., 2017) sehingga efektif untuk membantu siswa dalam memahami konsep-konsep yang bersifat abstrak (Alatas et al., 2017).

\section{KESIMPULAN}

Pembelajaran inkuri dengan simulasi PhET dinyatakan berpengaruh positif $(p<0,05)$ dan dapat meningkatkan keterampilan berpikir tingkat tinggi siswa pada materi bentuk dan perubahan energy. Hasil tersebut juga didukung peningkatan HOTs siswa setelah pembelajaran inkuri berdasarkan tinjauan tiap indicator yaitu analisis berkategori tinggi ( $\mathrm{n}$ gain: 0,8); evaluasi (n-gain: 0,7) dan mencipta (n-gain: 0,6) berkategori sedang.

\section{REKOMENDASI}

Penting untuk memperhatikan waktu yang dibutuhkan dalam melakukan percobaan agar pelaksanaan pembelajaran lebih efektif. Selain itu penggunaan establishing set yang autentik perlu dipersiapkan lebih baik untuk lebih mengkontekstualisasikan materi ajar dengan fenomena sekitar siswa

\section{DAFTAR PUSTAKA}

Alatas, F., Pohan, H., \& Nisa, A. S. (2017). The Implemention of Virtual Laboratory Phet Guided Discovery Learning on Students' Achievement: Dynamic Electricity Topic. 6165. https://doi.org/10.2991/icems-17.2018.13

Anderson, L. W., \& Krathwohl, D. R. (Eds.). (2001). A taxonomy for learning, teaching, and assessing: A revision of Bloom's taxonomy of educational objectives (Complete ed). Longman.

Annuuru, T. A., Johan, R. C., \& Ali, M. (2017). Peningkatan kemampuan berpikir tingkat tinggi dalam pelajaran ilmu pengetahuan alam peserta didik sekolah dasar melalui model pembelajaran treffinger. Educational Technologia, 1(2), 136-144.

Arends, R. (2012). Learning to teach (9th ed). McGraw-Hill.

Asy'ari, M., Fitriani, H., Zubaidah, S., \& Mahanal, S. (2019). The Science Process Skills of Prospective Biology Teachers in Plant Cell Material Based on Gender. International 
Journal of Emerging Technologies in Learning (IJET), 14(19), 168. https://doi.org/10.3991/ijet.v14i19.11208

Asy'ari, M., Hidayat, S., \& Muhali, M. (2019). Prototipe buku ajar fisika dasar reflektif-integratif berbasis problem solving untuk meningkatkan pengetahuan metakognisi. Jurnal Inovasi Pendidikan IPA, 5(2). https://doi.org/10.21831/jipi.v5i2.27089

Asy'ari, M., Prayogi, S., Mirawati, B., Syarifuddin, Hunaepi, Syahrir, \& Suhirman. (2021). Development of physics learning tools based on inquiry to increase creative thinking skills. Journal of Physics: Conference Series, 1816(1), 012094. https://doi.org/10.1088/1742-6596/1816/1/012094

Batuyong, C. T., \& Antonio, V. (2018). Exploring the Effect of PhET® Interactive SimulationBased Activities on Students' Performance and Learning Experiences in Electromagnetism. https://www.semanticscholar.org/paper/Exploring-the-Effect-ofPhET\%C2\%AE-Interactive-on-and-in-BatuyongAntonio/07ed9395b1fe4f154c97231e4c1a7604dee676d7

Brookhart, S. M. (2010). How to assess higher-order thinking skills in your classroom. ASCD.

Diansah, I., Suyatna, A., \& Viyanti. (2021). STEM-based physics multimedia design for stimulating HOTS on water and wind energy topic: Physics teacher perception. 1796(1), 012002. https://doi.org/10.1088/1742-6596/1796/1/012002

Eggen, P. D., \& Kauchak, D. P. (2012). Strategies and models for teachers: Teaching content and thinking skills (6th ed). Pearson.

Ennis, R. H. (2018). Critical Thinking Across the Curriculum: A Vision. Topoi, 37(1), 165-184. https://doi.org/10.1007/s11245-016-9401-4

Fitriana, V. N., Parno, P., \& Wartono, W. (2016). Pengaruh strategi flow diagram dalam pembelajaran inkuiri terbimbing terhadap keterampilan berpikir tingkat tinggi dan keterampilan proses sains. Jurnal Pendidikan: Teori, Penelitian, dan Pengembangan, 1(10), 1958-1963.

Fraenkel, J. R., Wallen, N. E., \& Hyun, H. H. (2012). How to design and evaluate research in education (8th ed). McGraw-Hill Humanities/Social Sciences/Languages.

Hake, R. R. (1999). Analyzing Change/Gain Scores*. 4.

Hunaepi, H., Firdaus, L., Samsuri, T., Susantini, E., \& Raharjo, R. (2020). Efektifitas Perangat Pembelajaran Inkuiri Terintegrasi Kearifan Lokal Terhadap Keterampilan Berpikir Kritis Mahasiswa. Scholaria: Jurnal Pendidikan Dan Kebudayaan, 10(3), 269-281. https://doi.org/10.24246/j.js.2020.v10.i3.p269-281

Ita, I. (2018). Keterampilan Berpikir Tingkat Tinggi dan Hasil Belajar Kognitif Siswa melalui Pembelajaran Kooperatif berbasis Inkuiri. Bioedukasi: Jurnal Pendidikan Biologi, 11(1), 23-28. https://doi.org/10.20961/bioedukasi-uns.v11i1.19734

Kusuma, M. D., Rosidin, U., Abdurrahman, A., \& Suyatna, A. (2017). The Development of Higher Order Thinking Skill (Hots) Instrument Assessment In Physics Study. IOSR Journal of Research \& Method in Education (IOSRJRME), 07(01), 26-32. https://doi.org/10.9790/7388-0701052632

Mahanal, S. (2019). Asesmen Keterampilan Berpikir Tingkat Tinggi. Jurnal Penelitian Dan Pengkajian IImu Pendidikan: E-Saintika, 3(2), 51-73. Scopus.

Mahulae, S. P., Sirait, M., \& Sirait, M. (2017). The effect of inquiry training learning model using PhET media and scientific attitude on students' science process skills. IOSR Journal of Research \& Method in Education, 7(5), 24-29.

Manalu, A. (2019). Pengaruh model pembelajaran inkuiri terbimbing (guided inquiry) terhadap higher order of thinking skills (hots). INPAFI (Inovasi Pembelajaran Fisika), 7(3), 9196. https://doi.org/10.24114/inpafi.v7i3.14797

Muhali, M. (2019). Pembelajaran Inovatif Abad Ke-21. Jurnal Penelitian Dan Pengkajian IImu Pendidikan: E-Saintika, 3(2), 25-50. Scopus.

Mystakidis, S., Berki, E., \& Valtanen, J. (2019). The Patras Blended Strategy Model for Deep and Meaningful Learning in Quality Life-Long Distance Education. Electronic Journal of E-Learning, 17(2). https://doi.org/10.34190/JEL.17.2.01

PhET Interactive Simulations. (n.d.). PhET. Retrieved January 15, 2021, from https://phet.colorado.edu/in/research

Prayogi, S., \& Muhali, M. (2015). Pengenbangan Model Pembelajaran Aktif Berbasis Inkuiri (ABI) untuk Mengembangkan Keterampilan Berpikir Kritis Mahasiswa. Prisma Sains: 
Jurnal Pengkajian IImu dan Pembelajaran Matematika dan IPA IKIP Mataram, 3(1), 21-26. https://doi.org/10.33394/j-ps.v3i1.1074

Pujiyono, P., Sudjito, D. N., \& Sudarmi, M. (2016). Desain pembelajaran dengan menggunakan media simulasi phet (physics education and technology) pada materi medan listrik. UPEJ Unnes Physics Education Journal, 5(1), Article 1. https://doi.org/10.15294/upej.v5i1.12708

Purnama, Y. I., \& Nurdianingsih, F. (2019). The Impact of Higher Order Thinking Skills (HOTS) Instructions in Teaching EFL Speaking Skill from the Perspective of Students' Motivation. Lingua Cultura, 13(4), 313-319. https://doi.org/10.21512/lc.v13i4.6105

Purnamawati, D., Ertikanto, C., \& Suyatna, A. (2017). Keefektifan Lembar Kerja Siswa Berbasis Inkuiri untuk Menumbuhkan Keterampilan Berpikir Tingkat Tinggi. Jurnal IImiah Pendidikan Fisika Al-Biruni [Journal of Physics Education Al-Biruni], 6(2), 209219. https://doi.org/10.24042/jipfalbiruni.v6i2.2070

Rohmawatiningsih, W., Rachman, I., \& Kodama, Y. (2018). Improving critical thinking skills and environment caring attitude through integrated environment-based learning model. Journal of Sustainable Development Education and Research, 2(1), 69-73. https://doi.org/10.17509/jsder.v2i1.12360

Singh, R., Singh, C., M, T. M. T., Mostafa, N., \& Singh, T. (2017). A Review of Research on the Use of Higher Order Thinking Skills to Teach Writing. International Journal of English Linguistics, 8(1), p86. https://doi.org/10.5539/ijel.v8n1p86

Sukaisih, R., Muhali, M., \& Asy'ari, M. (2020). Meningkatkan keterampilan metakognisi dan berpikir kritis siswa melalui pembelajaran model pemecahan masalah dengan strategi konflik-kognitif. Empiricism Journal, 1(1), 37-50. https://doi.org/10.36312/ej.v1i1.329

Thohari, U. H., Madlazim, M., \& Rahayu, Y. S. (2019). Developing Learning Tools Guided Discovery Models Assisted PhET Simulations For Trainning Critical Thinking Skills High School Students. International Journal of Multicultural and Multireligious Understanding, 6(4), 401-407. https://doi.org/10.18415/ijmmu.v6i4.1008

Thomas, G. P. (2012). Metacognition in science education: Past, present and future considerations. In B. Fraser, K. Tobin, \& C. J. McRobbie (Eds.), Second International Handbook of Science Education. Springer Netherlands. https://doi.org/10.1007/978-14020-9041-7

Yuliati, S. R., \& Lestari, I. (2018). Higher-order thinking skills (hots) analysis of students in solving hots question in higher education. Perspektif IImu Pendidikan, 32(2), 181-188. https://doi.org/10.21009/PIP.322.10

Zohar, A., \& Barzilai, S. (2013). A review of research on metacognition in science education: Current and future directions. Studies in Science Education, 49(2), 121-169. https://doi.org/10.1080/03057267.2013.847261

Zubaidah, S. (2019). Pendidikan Karakter Terintegrasi Keterampilan Abad Ke-21. Jurnal Penelitian Dan Pengkajian Ilmu Pendidikan: E-Saintika, 3(2), 1-24. https://doi.org/10.36312/e-saintika.v3i2.125 